\title{
Translating Sanskrit Mathematics
}

by

Satyanad Kichenassamy

University of Reims Champagne-Ardenne

satyanad.kichenassamy@univ-reims.fr 


\begin{abstract}
A discussion of Jean Michel Delire's Les mathématiques de l'autel védique. Le Baudhāyana Sulbasūtra et son commentaire Sulbadīpikā.

About the Author

SATYANAD KICHENASSAMY is professor of mathematics at the University of Reims Champagne-Ardenne. He was born in Paris in 1963, graduated from the École Normale Supérieure in Paris in 1986, and obtained his thesis in 1987 under the direction of Haïm Brezis. He works in mathematics, history and Indology, and has solved several long-standing problems in each of these fields. He introduced the method of Fuchsian reduction in nonlinear PDEs and the method of conformal snakes in computer vision. In history, he introduced the notion of apodictic discourse-motivated and conclusive discourse-in which rigorous proofs are encoded in a discursive structure.
\end{abstract}


he work to be discussed here, Les mathématiques de l'autel védique. Le Baudhāyana Sulbasūtra et son commentaire Sulbadīpikā [Delire 2016], is devoted to the translation from Sanskrit into French of a late commentary on an ancient Indian mathematical text, the Baudhāyana Śulvasūtra ${ }^{1}$ (BŚl). This text is dated ca 800-400 BC. ${ }^{2}$ It opens with a discourse on geometry, possibly the earliest mathematical discourse ${ }^{3}$ from India still extant. It continues with applications to the building of structures of very specific shapes required for "solemn" ritual purposes, by arranging and stacking bricks according to elaborate rules: these are the Vedic altar(s) of the title. There are mathematical constraints on the shapes of the bricks, on the overall shape of the structures, on the number of bricks and the total area that they cover, and on the relation between consecutive layers. The area-constraint in particular requires the elaborate tools described in the opening discourse.

Among Indian texts of the same class, $B S ́ l$ is the most complete and systematic, and in it we recognize ideas that were developed in later Indian mathematics. P.-S. Filliozat states in his preface that "[n]o text, in the immense mathematical literature in Sanskrit, better shows the originality of Indian Science" [vii-xi], an assessment not inconsistent with current scholarship. ${ }^{4}$ After recalling some of the mathematical aspects of $B S ́ l$ in $\S 1$, I summarize the contents of Les mathématiques de l'autel védique and relate it to earlier

${ }^{1}$ Also spelled "Śulbasūtra". Thibaut's sectioning of the text into three parts will be used, following established usage.

${ }^{2}$ For the arguments, see the introduction of Sen and Bag 1983. We give another, possibly new, argument for relative dating at p. 191 n22below.

3 Constructions are prescribed in earlier Indian texts, but they do not seem to have been woven into a connected discourse specifically devoted to geometry, emphasizing mathematical coherence and generality.

4 The back cover, however, claims that the

mathematical skills (savoir) of that time [scil. the first millennium BC] were comparable to the knowledge (connaissances) of civilizations of the same period as to content, but very different as to form, which reveals its oral character. 
works ( $(2)$. A few specific remarks on individual chapters follow ( $\$ 3$ ). Possibly because this book was written for Indologists rather than for historians of science, the mathematical concepts at work are not analyzed; in fact, the very existence of rigorous mathematical reasoning in India appears to be ignored, or even vigorously denied. ${ }^{5}$ The analysis of a typical example shows how essential aspects [\$4] were missed by focusing on a commentary that failed to account for the mathematical content of $B S ́ l$, and by performing incorrect mathematical transpositions of the correctly construed text. It seems that this neglect of mathematical issues reflects some aspects of the early historiography of the subject [\$5]. The review closes with a summary of the conclusions in a form hopefully useful to historians of science, whatever their area of interest.

1. The mathematical content of the Baudhāyana Śulvasūtra.

The Ślvasūtras ${ }^{6}$ or Aphorisms of the Cord $^{7}$ deal, as their name intimates, with constructions performed ultimately on the basis of a single cord that

5 The quotation opening the chapter entitled "The Mathematics of the Baudhayana Śulbasūtra" [63] refers to Hindus in general (les Hindous) in the following terms that we unfortunately must reproduce:

I can only compare their mathematical and astronomical literature, as far as I know it, to a mixture of pearl shells and sour dates, or of pearls and dung, or of costly crystals and common pebbles. Both kinds of things are equal in their eyes, since they cannot raise themselves to the methods of a strictly scientific deduction. [Sachau 1910, 1.25]

Delire quotes a French translation of the same judgment [Monteil 1996, 51-52]. Such inflammatory language may reflect the author's fear that an essential preconception is at threat. It could be, in this case, the belief that there is only one type of legitimate (mathematical) discourse.

${ }^{6}$ Four have been translated: the BŚl, the Āpastamba Ślvasūtra, the Kātyāyana Śulvasūtra, and the Mānava Śulvasūtra [Sen and Bag 1983]. They belong to four eponymous Vedic schools, each of which had its own Śulvasūtra. These four Śulvasūtras display significant differences. The third is very likely to be much more recent than the first two, and the last may be corrupt. Other texts of this class are described in Michaels 1978, and there is a word-index in Michaels 1983.

7 As Michaels has argued, «śulva», which may mean "cord” in general, must be taken in this context to refer to the topic, cord-geometry, rather than to the instrument; in fact, the latter is called rajju or spandya in BŚl, rather than śulva. We express this by capitalizing "Cord". For an analysis of this and other technical terms, see Michaels 1978, 156-170. 
defines the unit of length, all auxiliary lengths being derived from it. Constructions are performed on the ground, points being materialized by poles. The cord may be divided into any integral number of equal parts ${ }^{8}$ and may receive marks at distinct points. The unit-area is determined by the square whose side has unit length. The cord serves the purpose of both (marked) ruler and compass, and also enables one to determine perpendiculars. Symmetry with respect to an axis plays a central role. The isosceles trapezium is the most important figure after the oblong, and seems to be the substitute for the scalene triangle. ${ }^{9}$ The primacy of quadrilaterals (preferably symmetric) over trilaterals is still apparent in much later mathematical texts. All figures are ultimately exact transformations of squares, with the exception of the circle, for which rules for approximate quadrature/circulature ${ }^{10}$ are given. Thus, any figure is determined by the sequence of operations required for its construction, starting from the unit-cord. Because each figure is defined by such a sequence, the scaling of figures is accomplished simply by changing the unit of length and by going through the same sequence of operations. Here, number is embedded in geometry through the scalable unit of length. Much attention is devoted to transforming one figure into another without a change of area. Since figures are obtained by area-preserving or scaling transformations, or by starting from squares of prescribed areas, the area of every figure is determined by its very construction. Baudhāyana never uses angles, parallels, or a calculus of fractions. ${ }^{11}$ A scale-calculus serves as a substitute for the latter [Kichenassamy 2006]. The possibility of carrying out

${ }^{8}$ In a later section, alternative constructions involving a bamboo rod with holes bored at distinguished points are described [BŚl $3.13^{-15}$ ]. The restriction to the cord in the opening section seems, therefore, to be deliberate.

9 An isosceles trapezium is divided by a diagonal into two scalene triangles with the same height.

10 That is, rules for transforming a circle into a square of the same area, and conversely.

11 In other words, at no point is a magnitude associated with the intersection of two lines. Angles do not seem to occur even in later texts [Kichenassamy 2010, 2012a, 2012 b]. They are never needed: relations between oblongs or quadrilaterals, or the trilaterals that they contain, provide all the required tools. For instance, the Indian sine and cosine-attested from the middle of the first millennium AD onwards-are obtained by associating to an arc of a circle the sides of the obvious "right triangle". The standard argument for the Indian origin of our sine function may be found for instance in Filliozat 1988, 261. As was stressed in the French (Bourbaki) school, the measure of an angle is by no means a primary or elementary notion: it ultimately requires the rectification of an arc of a circle. 
geometric operations without error is taken for granted in $B S ́ l$, as in Euclid's Elements for that matter.

Like most important works of Indian mathematics, the Śulvasūtras are discourses, typically unwritten and meant to be memorized. This feature seems to have been conducive to the abstraction of mathematical concepts, and to account for the absence of diagrams in $B S ́ l$ and all major Indian mathematical texts. Baudhāyana is thought to have introduced the notion of paribhāṣā (meta-discourse), a discourse comprising statements that govern the way other statements are to be understood:

[T] he innovation [of his] that would turn out to be most important, at least through its indirect effects, is that of the paribhāss $\bar{a}, \ldots$ axioms that must be present in the user's mind.... Baudhāyana may have been the first to introduce p[aribhāṣās], as they seem to play [in his works] a more necessary role than elsewhere. [Renou 1963, §15, 178-179]

The introductory section, $B S ́ l$ 1.1-62, seems to be such a meta-discourse. Units and subunits of measurement are defined first, stressing that some of them may be redefined at will [1.1-21]; this freedom is the basis for the scaling of figures. Next, the text describes how to construct a square, an oblong, or an isosceles trapezium, and a special type of isosceles triangle.

Proposition $1.48^{12}$ expresses that the diagonal cord of an oblong makes by itself what the two dimensions ${ }^{13}$ of the oblong separately make. In other words, first construct one figure ${ }^{14}$ by taking one side of the oblong as unit of length. Then, construct another figure by performing the same sequence of operations with the other side of the oblong as unit of length. Next, produce a third figure using the diagonal cord as unit-cord, with again the same sequence of operations. The conclusion is that the third figure is equivalent in area to the first two figures together. This proposition is applied to the construction of a square with an area equal to the sum (or difference) of two given squares.

These methods of sum and difference are relevant for the transformation of a square into any one of a class of figures without a change of area. Approximate rules for the circulature of a square and its inversion, the quadrature of the circle, are also given [1.58-6o]. The meta-discourse closes with a famous

12 dīrghacaturaśrasyākṣnayārajjuḥ pārśvamānī tiryañmānī ca yatprthagbhūte kurutastadubhayam karoti.

13 Literally, the side-measure and the cross-measure (pārśvamānī tiryañmānī ca).

14 Possibly a square, but the text does not spell this out. 
approximation of the diagonal of the square [1.61-62] that is accurate to four places (in modern terms); its place here is logical, since it is a consequence of the derivation of the rules for quadrature [1.59-60: Kichenassamy 2006]. The text continues with a detailed exposition of how, on the basis of these general results, one may construct brick structures that may be described as multilayered jigsaw puzzles of precise shapes and prescribed areas. They are often referred to as altars in the secondary literature because of the central place of fire in the ritual. The pieces are square or oblong kiln-fired bricks or subdivisions and combinations of the same.

\section{The content of Les mathématiques de l'autel védique}

As its full title shows, the work under review approaches the text through one of two extant commentaries, designated as Ślbadipikā (ŚD), by Dvārakānātha Yajvan. ŚD appears to have been composed between AD 1434 and 1609. ${ }^{15}$ There is general agreement that the commentator's remarks do not shed light on Baudhāyana's modus operandi. Rather, they illustrate how this sūtra was reinterpreted in a particular school, with emphasis on its applications to ritual. Les mathématiques de l'autel védique also attempts to draw parallels with other cultures, but no clear structure or hypothesis about transmission emerges from it. The work seems to be intended for Sanskrit readers, as is suggested by the use of the Nāgarī script for the edited text, including the footnotes.

Les mathématiques de l'autel védique is an update of three earlier works:

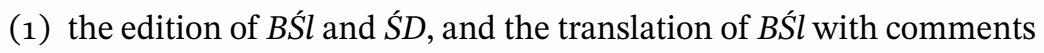
by Thibaut [1875a, b];

(2) the edition by Bhațtācārya [1979] of two commentaries on $B S ́ l$, including $S D$, with a more extensive set of diagrams; and

(3) Sen and Bag $1983,{ }^{16}$ with remarks on commentaries as well as a modern commentary.

15 Delire's argument for this dating is as follows [150-160]. It appears that the commentator "borrowed" from Sundararāja's commentary on the Āpastamba Śulvasūtra, although not in a "slavish" manner [146]. There are two manuscripts of the latter, one from 1581 and the other from 1588 [150]. Although Datta [1932, 18] considers Sundararāja to be the later of the two commentators, Delire opines with Gupta [1993] that Sundararāja's work is earlier than Dvārakānātha Yajvan's but later than the Ślba-Vārtika (1434) by Rāma Vājapeyin. On the other hand, there is a copy of Dvārakānātha Yajvan's commentary that is dated to 1609 .

${ }^{16}$ See p. $186 \mathrm{n} 6$ above. 
It differs from them in three respects:

(1) it takes into account a greater number of manuscripts;

(2) it provides a French translation of the commentary; and

(3) it includes a more complete set of diagrams-in particular, it addresses in some detail the relative position of the various brick structures within the ritual area [42-55]. The diagrams are, of course, an editorial addition.

This volume is an expansion of the author's thesis [Delire 2002] "elaborated under the supervision of P.-S. Filliozat".

The first part [1-191] contains four chapters devoted respectively to:

(1) technical and social aspects of ritual [3-61],

(2) the mathematics of $B S ́ l$ 1.22-62 [63-123],

(3) the mathematics of the commentators [125-160], and

(4) the manuscripts taken into account and the editorial choices made [161-191].

The second part [193-363] gives the (French $\left.{ }^{17}\right)$ translation of the text and commentary. It also provides a transliteration of $B S ́ l$ in roman script. There is no running commentary by the editor in this part.

The third part ${ }^{18}$ contains the Sanskrit text [369-515], followed by the editor's diagrams [519-578]. Thibaut's sectioning is used. The 21 sections marked off by Bag and Sen are also indicated in part 2. There is also a further, intermediate sectioning. ${ }^{19}$

A name and place index [581-587], a partial ${ }^{20}$ Sanskrit index [598-597], a list of references (works cited and manuscript catalogs [601-613]), and a table of contents [615-620] close the work.

The edition was established by basing the first two parts of $B S ́ l$ on 13 manuscripts, selected from about 30 manuscripts, in addition to Thibaut's edition of the text and commentary [1875a, b], which was itself based on three

17 The few peculiarities of Belgian French (such as «nonante» for "ninety") do not pose any difficulty.

18 Page numbers in this part are also given a numbering in Nāgarī characters.

19 To take a typical example, Bag and Sen group Thibaut's 1.29-35 as 1.5. In the volume under review, they form two unnumbered groups: 1.29-31 are listed on three consecutive lines, each preceded by «sū» (for «sūtra»), followed by a paragraph of commentary preceded by «dvā» (for «Dvārakānātha Yajvan »). Then come 1.32-33, similarly grouped together.

${ }^{20}$ As compared with Michaels 1983. 
manuscripts of text and commentary, and a fourth one with the text alone. He did not have access to all of the manuscripts mentioned in the work but gives full particulars including location for all of them. There is no stemma codicum. ${ }^{21} \mathrm{~A}$ few emendations for $B S ́ l$ itself are proposed, mostly for part 3 [162-166]. These generally confirm Thibaut's suggestions or correct misprints and "obvious errors" («erreurs manifestes») that are readily detected by carrying out the constructions or the implied computations.

\section{Analysis and specific remarks}

The title of part 1-"Mathematical Methods in the Architecture of Solemn Sacrifice (sacrifice solennel) of Ancient India"-makes the outlook of the work clear. The focus here is on public sacrifices (as opposed to domestic rites) involving brick structures, performed by householders [16] and considered as requiring methods akin to mathematics and architecture. The more complex public rituals are organized by hired experts who act on behalf of the yajamāna, whose needs or personal desires are the primary motivation for the rite. The Ślvasūtras are manuals for those experts who may not have the same outlook or desires as the yajamāna. Since these rites require larger structures than the domestic ones, they may require greater precision. It appears that the need for precision, together with ritual exactness, was instrumental in the development of a new, more rigorous geometry. Delire refers to Seidenberg's speculation about a possible ritual origin of Greek and Indian geometry [65: see, e.g., Seidenberg 1962]. Les mathématiques de l'autel védique also explicitly excludes from consideration the two later stages of life beyond the stage of householder, stages generally associated with the philosophical investigation of the meaning of texts and the reinterpretation of ritual [16]. ${ }^{22}$

Chapter 1.1 is entitled "The Sacrificial Ground". It contains a description of ritual structures, focusing on their interpretation in the commentary that is translated in this work-there is some variation among authors-together with a collection of comparisons that have been made in the past with elements of other cultures. A political interpretation of ritual seems to be

21 Perhaps the implication is that all manuscripts belong to a single family.

22 This would have given an argument for relative dating: Kața Upanișad 1.1.15 [Radhakrishnan 1953, 601] refers to the introduction of another brick structure, not mentioned in BŚl. If it is an innovation, this proves that Baudhāyana's geometry predates the Kața Upanișad. 
suggested, perhaps unwittingly: "When the Vedic nation (le peuple védique) $)^{23}$ settles somewhere, it takes possession of the territory by a sacrifice" [15]. On the same page, we read: "[O]ne of the altars (foyers)...symbolizes conquered and managed (conquis et exploité) territory." The question whether those social aspects were essential ingredients in the emergence of geometry does not seem to be addressed.

Les mathématiques de l'autel védique mentions the existence of patterns involving circles, the intersections of which are the vertices of squares, in the Indus Valley and in Heraklion, suggesting that similar patterns "most certainly led to" («ont très certainement débouché sur») an exact construction of a square in BŚl [69-71]. The implied thesis is not clear: Did Baudhāyana create an abstract discourse on the basis of ornamental patterns in order to improve ritual performances? Or is mathematical discourse an outgrowth of solemn ritual, a response to challenges to this ritual. Or is it only incidentally associated with it? There are indeed suggestions that the Ślvasütras were an outgrowth of the geometry and architecture of an earlier culture, such as the Indus Valley Civilization, or some other with a sophisticated kiln-fired brick technology [Converse 1974; Staal 1999 and 2001]. Whatever its remote forerunners, it appears at the present time that Baudhāyana's approach, by its discursive structure, not only differs from extant texts from other cultures, but also represents a new stage in the evolution of Indian tradition.

Chapter 1.2 is devoted to Baudhāyana's mathematics and presents a translation of the results into modern symbols, together with speculations about their possible origins, collecting some of the opinions that have been put forward in the past. BŚl 1.22-62 are termed "mathematical sütras" (in the title of section 1.2.1), implying that this part of the text qualifies as mathematics while the rest would be ritual. The missing part of the meta-discourse, $B S ́ l$ 1.1-21, is described in the chapter on ritual [\$1.1.3]. This part introduces the variability of the unit of measurement, which forms the basis of the scaling of figures in $B S ́ l$. Delire does recognize in it "a principle of proportionality enabling one to construct objects similar to others by simply adjusting the base measure" [19], suggesting that this part, too, is mathematical. It is true that the commentators also missed most of the mathematical issues and did not realize that their own conceptual framework differed from Baudhāyana's.

23 The existence of such a well-defined Vedic ethnic or political entity, let alone its bellicose nature, is highly controversial. The existence of similarities between IndoEuropean languages is not. For a recent discussion of this issue, see Demoule 2014. 
This chapter also contains a collection of some of the earlier suggestions about the possible derivation of Baudhāyana's results. The author mentions Piaget's analysis of the stages of learning observed in some children as a possible model for the evolution of Indian mathematics, and reads earlier derivations based on dissection methods in this light [9o ff.]. But Baudhāyana is working within a complex tradition that he has already assimilated; we are not dealing with the infancy of mathematics but with its coming of age. Ancient mathematics does not seem to have been performed by children, even in the remote past. Also, Piaget's praxis-driven model, as presented by Delire, does not account for the discursive dimension of $B S ́ l$. Mention of dissenting views on these controversial issues, such as those of Chomsky or Lacan, would have been welcome.

Chapter 1.3 is devoted to "the commentators' mathematics". Their results seem to have been obtained by using the methods that have been standard in India since Āryabhața (AD 499). This chapter records inconsistencies "certainly to be attributed" to borrowings from other sources, without doublechecking [144]. It closes with a detailed comparison of parallel passages in the commentary edited here and with Sundararāja's commentary on the Āpastamba Śulvasūtra, leading to Delire's proposed timeframe for the commentary [150-160]. ${ }^{24}$

Some aspects of the translations may be misleading to the non-specialist. Some of them are perhaps due to carelessness and have the effect of hiding conceptual problems from view. Here are three examples.

(1) The archaic term «praüga» for the isosceles triangle obtained from a square by joining the middle of the top side to the ends of the lower side is translated by "triangle" [BŚl 1.56: 208]. Now, words equivalent to "triangle" or, more precisely, "trilateral” («tribhuja») are absent from $B S ́ l ;{ }^{25}$ so is the very notion of a scalene triangle.

(2) Single terms are not always translated uniformly: «pāśa» is translated by «boucles» (loops) in 1.27 and in the commentary to 1.30, but by «noeud» (knot) in 1.30 itself. The technological issue is how, given a cord of known length, one may fit loops, or perhaps nooses, at its ends in such a way that, by stretching the cord between two poles, one is guaranteed that the distance between them is equal to the length of the original cord. Knotting a cord slightly reduces its length.

${ }^{24}$ See p. 189 n15 above.

25 According to Michaels 1983. 
Such points confirm the lack of emphasis on practical issues in $B S ́ l$ that were perhaps to be left to the care of specialized staff. Similarly, «vidha» is translated as «unité» unit) and as «sorte» kind, "type") [see BŚl 2.11-12, 2.14]. Bag and Sen translate it as "fold" because, for instance, «saptavidha» means sevenfold: it qualifies the figure obtained from a given one by increasing its area sevenfold. This technical term reflects the conception of scaling of figures by the mere change of the fundamental cord [see $\S 2$, p. 189above]. The translation of «tiryañmānī» and «tiraścī» for a transverse dimension [1.54, 3.281]) as «transversale» is also misleading because of the existence in modern mathematics of the "théorie des transversales", in which a transversale is a line that cuts through several others. On page 81, Delire had correctly translated the first of these words as «mesurée en travers » (measured across). ${ }^{26}$ Readers already familiar with the subject will hopefully make the necessary adjustments.

(3) The very first line of the commentary is a prosternation to Ganeśa ( «śrī gaṇeśāya namaḥ»: «śrī» is honorific). In the translation, this clause is moved after 1.1 and translated approximately by "Glory to Ganeśa". It is a prosternation and not praise; and it is essential that it should come first since it is a standard way for authors to ward off, at the outset, obstacles of any kind that might arise in the course of the work.

We now turn to the basic questions outlined in the introduction about the neglect of the conceptual and discursive dimensions of the text.

4. The problem of mathematical transposition

4.1 An example of mathematical transposition As a typical example of transposition in Les mathématiques de l'autel védique, consider Baudhāyana's rule [1.59] for the (approximate) quadrature of the circle. We read:

Let us note at the outset that Dvārakānātha [the commentator] did not feel any difficulty in understanding Baudhāyana's quadrature. Indeed, he transforms the fraction ${ }^{27} 1-\frac{28}{8 \times 29}-\frac{1}{8 \times 29 \times 6}+\frac{1}{8 \times 29 \times 6 \times 8}-$ for this is indeed how sūtra (I.59) is

${ }^{26}$ An oblong constructed symmetrically with respect to an axis has two dimensions, one along this axis, the other one across it.

${ }^{27}$ Here and in the next sentence, the wording is ambiguous. The French verb used is "comprendre»; it can mean "to understand" or "to comprehend". The commentator construed the sentence correctly in the mere grammatical sense, but he did not comprehend it, as we shall see. 
to be understood [my emphasis] -into $\frac{7}{8}+\frac{1}{8}\left(\frac{41}{1392}\right)$, then further into $1-\frac{1}{8}\left(\frac{1351}{1392}\right)$, thus showing his mastery of the calculus of fractions, even [when they are] not unit[-fractions]. ${ }^{28}[142]$

The implication is that

(a) Baudhāyana's text may be written in a form in which a possible allusion to "Egyptian fractions" is apparent, thus introducing unit-fractions that are not in the text; and

(b) since the commentator could handle general fractions, there is no need to investigate whether Baudhāyana worked with this concept.

However, point (a) is incorrect: this is not how the sūtra is to be understood. To see this, consider Thibaut's translation of 1.59-the way in which Thibaut construed the text has never been challenged, not even in the volume under review, since the Sanskrit is quite clear. His translation reads:

If you wish to turn a circle into a square, divide the diameter into eight parts and one of these parts into twenty-nine parts: of these twenty-nine parts remove twenty-eight and moreover the sixth part (of the one part left) less the eighth part (of the sixth part). [Thibaut 1875b, 1.59]

Taken literally, and with the same notation as Les mathématiques de l'autel védique, the text would correspond to the expression:

$$
1-\frac{1}{8 \times 29}\left(28+\frac{1}{6}\left(1-\frac{1}{8}\right)\right) \text {. }
$$

Thus, in terms of fractions, one would have to deal with a compound expression of which the numerator could itself be a fraction-in no sense is this mathematical object a sum of unit-fractions. Now, there is general agreement that a general calculus of fractions with reduction to the same denominator is not attested at this time. And all attempts to account for 1.59 by means of a calculus of fractions lead to inconsistencies [Kichenassamy 2006]. The question is: What mathematical tool, possibly absent from modern mathematics, was used by Baudhāyana in those situations where we would be tempted to use general fractions or "Egyptian" fractions? The work under review and the commentary missed this question because they performed an incorrect mathematical transposition on top of the unproblematic literal translation. ${ }^{29}$ This transposition made it impossible to see

28 A unit-fraction is one of the form $1 / n$, where $n$ is integral. Calculations with aliquot parts are found in Egyptian mathematics; hence, the name "Egyptian fractions" for expressions involving only sums of unit-fractions.

29 Thibaut also performed this mathematical transposition, although he did point out some of the anachronistic aspects of the commentary. 
the problem. Recall that, according to the back cover [cf. p. $185 \mathrm{n} 4$ above], the author considers that all works of the same time frame are essentially similar in content. The mathematical transposition is driven by the illusion that the text must involve unit-fractions.

Now, the mathematical object involved in 1.59 is not a combination of fractions such as $13 / 15$, even though it is determined by pairs of numbers such as $(13,15)$. One may think of each of them as a "pairs of divisors", in which none of the elements is distinguished as the numerator. Such pairs express a correspondence between lines or, rather, (portions of) cords [Kichenassamy 2006, 2011]. For instance, 1.60 states: "after having made fifteen parts, remove two". That is, to 15 parts of one cord correspond $13(15-2)$ of another. This pair is not a fraction because the two numbers play symmetric roles. If there is only one such pair, it is readily inverted without reference to fractions. In this case, it suffices to divide the latter cord into 13 parts and to add two of these parts to recover the length of the first cord.

More generally, two cords, $a$ and $b$, would be related by giving a pair $p, q$ of divisors if the following holds: if one divides $a$ into $p$ parts, then $q$ of them make up $b$. And if one divides $b$ into $q$ parts, then $p$ of them make up $a$. If we read the text closely with this idea in mind and remember that the unit or length may be redefined in the course of the argument, we see that the text lists, in a remarkably compact yet transparent way, the steps of a derivation of 1.59 and of the following few propositions, using only tools attested in the text [Kichenassamy 2006, 172-180]. This derivation differs from all those proposed so far, and it cannot be recovered by mere transposition from some modern derivation. It accounts for the very specific numbers in the text, as well as the order of the words in the sentence, and is, to date, the only one that accounts for the text as it is.

Thus, Les mathématiques de l'autel védique, by relying on the commentary, is affected by the belief that mathematical transposition may be made without loss of content. However, transposition is by no means tautological..$^{30}$ That Indian commentaries make use of a form of transposition does not make it legitimate in historical work. Change of notation, however, can be harmless provided that the operations performed on the new symbols reflect those of

30 Transposition may be useful in the study of mathematical problems to gain new insight, but becomes objectionable when it leads to attributing one's own ideas to someone else. 
the text. ${ }^{31}$ Modernized notation becomes dangerous only when it suggests relations that could not have been suspected without it.

4.2 Is mathematical transposition unique? It has been argued ${ }^{32}$ that mathematical transposition is nevertheless a legitimate tool in the analysis of mathematical texts, not only because it has been performed in some ancient texts, but because it is allegedly the only way to make sense of a text. To our knowledge, the only example on this score is the algebraic interpretation of four "lost" books of Diophantus in Arabic sources of the late ninth century, in which Diophantus is turned into al-Khwārizmī's "heir" («successeur») ${ }^{33}$ (sic). This text was further reinterpreted in terms of 20 thcentury algebraic geometry, occasionally requiring spaces of more than three dimensions. Mathematical transposition is claimed in this case to be not only convenient but necessary because it is unique. But in fact, it is not. This transposition requires the introduction of several unknowns not attested in the text, but we know that Brahmagupta (in the seventh century) introduced several literal unknowns. Moreover, we find, for example, in a ninth-century commentary, ${ }^{34}$ an equation with six unknowns labeled by letters $(y \bar{a}, k \bar{a}, n \bar{l}, p \bar{l}, l o, h a)$ that are the initials of a conventional set of words and bear no connection to the quantities represented. ${ }^{35}$ Thus, a literal algebra with several unknowns, unrelated to the conception of a space of more than three dimensions, is attested at the same time as our Arabic text. We must, therefore, wonder, regardless of any possible hypothesis about transmission, why one particular transposition was preferred by some modern readers to another. At any rate, this proves that mathematical transposition into 2oth-century mathematics is not the only possible transposition. We also

${ }^{31}$ An example is provided by the introduction, in the analysis of $B S ́ l 1.59$ above, of the pair-notation for the benefit of the modern reader. The derivation in Kichenassamy 2006, however, does not use it and does not introduce other symbols.

32 We thank Karine Chemla for bringing this problem to our attention. Chemla 1986 gives an overview and is careful not to jump to conclusions.

33 Chemla 1986, 368.

34 Colebrooke 1817, 355 et pass. See also $139 \mathrm{n} 1$ for details on this multi-literal algebra and its development.

35 "Letter" here translates «varṇa». This word also means "color", hence, the use of the initials of names of colors, as here. Other lists of letters as symbols are also attested. Those letters are further analyzed into phonemes in Indian grammars, but this is not relevant here. 
see in this example that appropriation through mathematical transposition is by no means a recent phenomenon.

5. Other reasons why conceptual issues in Indian mathematics were neglected

The belief that mathematical transposition is harmless fosters the feeling that texts do not constrain our readings of them, that internal analysis is not necessary. Leaving aside prejudice and disregard of axiological neutrality, there seems to have been three further reasons for the relative dearth of textual analyses of Indian texts in their own terms:

(1) the existence of undetected errors in the texts,

(2) the (related) assumption that results found in Indian texts were derived from unacknowledged sources, and

(3) the belief that ancient mathematical discourse may be understood on the basis of much later sources of the same tradition.

I examine them in order.

(1) The existence of errors ${ }^{36}$ propagated by commentaries suggested that some results

were handed down as received truths, with the result that incorrect theorems were not identified as a matter of routine by any student who checked the proofs. [Bronkhorst 2001, 54]

Some commentaries were blamed for striving to justify the incorrect ones [Bronkhorst 2006]. However, undetected errors and ideologically driven discourses are not unheard of, even in modern mathematics. The issue is, therefore, whether such commentators are representative of the entire tradition and, indeed, whether there may not have been several mathematical cultures in India.

(2) It was assumed that Indian mathematics was influenced by Hellenistic mathematics, which may be true to some extent for late authors, just as

36 A famous example is Āryabhața's rule that appears to give an incorrect formula for the volume of the sphere [Äryabhațiya 2.7]. The error was not spotted in the oldest extant commentary, by Bhāskara I (AD 629, translated in Keller 2006, 1.xxxii-xxxiii): Keller points out that the commentator seems to work with a faulty version of the text [2006, 1.35 nn209-210]. Since there is an ingenious way to make sense of the passage [Elfering 1975, 71-76], we must conclude that the commentator missed the error and failed to propose a mathematically correct reading of the text, even though one was possible. 
Indian mathematics influenced other cultures. Hellenistic influence ${ }^{37}$ on genethliacal astrology is documented and acknowledged in the texts, but interpretative astrology - the subject of a vast literature in India as elsewhere-does not seem to be discussed at all in mathematical texts. Also, the absence of the notions of angle and parallel in India shows that, for instance, the conceptual framework of Brahmagupta's geometry (AD 628) does not seem to have a counterpart in other cultures. The transmission hypotheses formulated so far do not seem to account for Brahmagupta's text. More generally, it is essential to refrain from speculating on issues of transmission before the content of the texts has been thoroughly studied. Issues of priority must not become a priority.

(3) Since ancient Indian mathematical texts were preserved faithfully by tradition to this day, their meaning may perhaps be inferred from late commentaries. However, this is not always warranted. To take an example, the existence of several schools with non-equivalent conceptual frameworks ${ }^{38}$ is indicated by a passage in which Bhāskara II (12th century) criticizes Brahmagupta's formula ${ }^{39}$ for the diagonals of a cyclic quadrilateral as unnecessarily complicated. He gives a simpler formula that does not, however, apply to all the cases covered by Brahmagupta's [Colebrooke 1817, 80-81]. It seems established [Kichenassamy 2012b] that there were partial breaks in the continuity of the Indian mathematical tradition, so that texts were passed down to further generations but their conceptual framework or the associated modus operandi was partially lost in the process.

37 Probably before the seventh century AD. The date and nature of this influence have recently been reexamined, and an error in the reading of an important text was discovered in the process. See Mak 2013; Filliozat 2016.

38 The existence of two distinct schools in India-one that deals exclusively with cyclic quadrilaterals; another that never considers them-seems to have been first clearly singled out as a fundamental issue in Sarasvati Amma 1999, 81.

39 Many Indian texts describe in words general formulae-for the determination of lengths, areas, or volumes for instance-where variables are represented by words, as is appropriate for versified texts. The existence of separate names for parts of a figure makes the correspondence with modern formulae unambiguous. This system coexists with literal or symbolic algebra among authors who also deal with the theory of equations. 


\section{Conclusion}

Les mathématiques de l'autel védique is a contribution to the study of an important text, the Baudhāyana Śulvasūtra, and will be of interest to those Indologists already familiar with the basic texts of ancient Indian mathematics and the issues that they raise. However, the very existence of rigorous mathematical reasoning in this text is not apparent in this study because Delire focuses on a late commentary that failed to address conceptual issues, introduced mathematical transpositions in terms of a much later framework, and did not account for the text itself.

We attribute this state of affairs to two main causes. First, the Baudhāyana Śulvasūtra, while an apodictic discourse, is not dogmatic: it requires the reader to think with the author rather than to be submissive. Second, there were partial breaks in the mathematical tradition: the conceptual framework of one school was forgotten while its texts were passed down; its results were thus fitted to the Procrustean bed of another school, resulting in inconsistencies that indirectly cast a shadow on the original works.

However, the correct conceptual framework of the Baudhāyana Śulvasūtra may be understood by textual analysis because the text was composed with great care. Insofar as text and context are correlated in this case, internal analysis provides strong evidence for the context that is more reliable than second-hand information. And the mathematical coherence of this text is a very strong constraint on its reading, as it is for the reading of any mathematical text. The notion of apodictic discourse that includes all forms of rational argumentation to establish a result within a shared framework seems relevant to the analysis of texts from other cultures as well..$^{40}$

The following conclusions appear to be of relevance to the analysis of all cultural areas.

(1) Mathematical transposition from one conceptual framework to another is a form of tampering with the text. By contrast, transcription into modern notation is sometimes admissible, provided that the operations permitted are never lost sight of, and may help communication with modern readers.

(2) Priority is not a priority. Transmission or issues of priority should not be discussed before analyzing and understanding the texts themselves.

40 See Kichenassamy 2015 for an application to an Italian text of the Renaissance. 
(3) Consistent scientific discourse, ancient or modern, takes the form of an apodictic discourse that need not take a deductive form, unless one wishes to suppress motivation and stress verification.

(4) There may be mathematical pluralism within a culture. ${ }^{41}$ In particular, a text and a commentary on it may not share the same conceptual framework. Any plural tradition will perforce appear incoherent or inchoate at best, if one attempts to interpret individual differences as forms of variability within categories implicitly taken as universal.

The analysis of mathematical discourse, guided by the demands of the internal mathematical coherence of each individual text and strict axiological neutrality, is similar to ordinary communication: other peoples' discourses are seldom entirely transparent and are understood through a process of gradual adjustment, provided that we accept that we do not know beforehand what others mean. It is possible to understand others without becoming similar to them or forcing them into assimilation. In this sense, the process of analysis advocated here provides a framework for the understanding of diversity.

\section{BIBLIOGRAPHY}

Bhaț̣āaārya, V. 1979. Baudhāyanaśulbasūtram, with Two Commentaries: «Bodhāyanaśulbamīmāmssā», by Śrī Vyañkatẹeśvara Dīkṣita, and «Ś́ badīpikā», by Śrī Dvārakānātha Yajva. Benares.

Bronkhorst, J. 2001. "Pāṇini and Euclid: Reflections on Indian Geometry". Journal of Indian Philosophy, 29: 1-2, 43-80.

2006. "Commentaries and the History of Science in India". Asiatische Studien / Études Asiatiques, 60: 773-788.

Chasles, M. 1837. Aperçu historique sur l'origine et le développement des méthodes en géométrie. Brussels. Reprint: Sceaux, 1989.

Chemla, K. 1986. “II. Étude mathématique”. See Chemla, Morelon, and Allard 1986, 361-375.

2016. "La diversité des cultures mathématiques. Un passé et quelques futurs possibles". Gazette des Mathématiciens 150: 16-30.

41 For a very recent example of pluralism, see Chemla 2016, 2018. She points out the lack of definition of the term "mathematical cultures" [Chemla 2016, 1]; the notion of conceptual frameworks may provide a useful substitute. 
Chemla, K. 2018. "How Did One, and How Could One Have Approached the Diversity of Mathematical Cultures?” Pp. 1-61 in V. Mehrmann and M. Skutella edd. Proceedings of the European Congress of Mathematics, Berlin, 18-22 July 2016. Paris.

Chemla, K.; R. Morelon; and A. Allard. 1986. "La tradition arabe de Diophante d'Alexandrie. À propos de quatre livres des Arithmétiques perdus en grec, retrouvés en arabe". L'Antiquité Classique 55:351-375.

Colebrooke, H. T. 1817. Algebra, with Arithmetic and Mensuration, from the Sanskrit of Brahmegupta and Bhascara. London. Reprint: Delhi, 2005.

Converse, H. S. 1974. “The Agnicayana Rite: Indigenous Origin?” History of Religion 14: 81-95.

Datta, B. B. 1932. Ancient Hindu Geometry (The Science of the Śulba). Calcutta. Reprint: Delhi, 1993.

Delire, J.-M. 2002. Vers une édition critique des Śulbadīpikā et Śulbamīmāmsāa, commentaires du Baudhāyana Śulbasūtra . Contribution à l'histoire des mathématiques sanskrites. 2 vols. PhD dissertation, Université libre de Bruxelles. Brussels. 2016. Les mathématiques de l'autel védique. Le Baudhāyana Sulbasūtra et son commentaire Sulbadīpikā. Geneva.

Demoule, J.-P. 2014. Mais où sont passés les Indo-Européens? Paris.

Elfering, K. 1975. The Mathematik des Āryabhața I. Translation from Sanskrit and Commentary. Munich.

Filliozat, P.-S. 1988. "Calculs de demi-cordes d'arc par Āryabhața et Bhāskara I”. Bulletin d'études Indiennes 6: 255-274. 2016. “La nature des planètes selon le Yavanajātaka 'L'Horoscopie grecque' de Sphujidhvaja et le Bṛhajjātaka 'La Grande Horoscopie' de Varāha Mihira”. Pp. 341-359 in J. Jouanna, V. Schiltz, and M. Zink edd. La Grèce dans les profondeurs de l'Asie. Paris.

Gupta, R. C. 1993. "Sundararāja's Improvement of Vedic Circle-Square Conversions”. Indian Journal of History of Science 28: 81-101.

Keller, A. 2006. Expounding the Mathematical Seed: A Translation of Bhåskara I on the Mathematical Chapter of the Āryabhatịya. 2 vols. Basel.

Kichenassamy, S. 2006. "Baudhāyana's Rule for the Quadrature of the Circle”. Historia Mathematica 33: 149-183. 2010. "Brahmagupta's Derivation of the Area of a Cyclic Quadrilateral”. Historia Mathematica 37: 28-61. 
Kichenassamy, S. 2011. "Textual Analysis of Ancient Indian Mathematics". Gaṇita Bhāratī 33: 15-28. 2012a. "Brahmagupta's Propositions on the Perpendiculars of Cyclic Quadrilaterals". Historia Mathematica 39: 387-404. 2012b. "L'analyse littéraire au service de l'histoire des mathématiques. Critique interne de la géométrie de Brahmagupta”. Comptes-Rendus des Séances de l'Académie des Inscriptions et Belles-Lettres 2: 781-796. 2015. "Continued Proportions and Tartaglia's Solution of Cubic Equations". Historia Mathematica 42.4: 407-435. For an introduction, see http://www.cnrs.fr/insmi/spip.php?article1477.

Mak, B. M. 2013. “The Date and Nature of Sphujidhvaja's Yavanajātaka Reconsidered in the Light of Some Newly Discovered Materials". History of Science in South Asia 1: 1-20.

Michaels, A. 1978. Beweisverfahren in der vedischen Sakralgeometrie. Wiesbaden. 1983. A Comprehensive Śulvasūtra Word Index. Wiesbaden.

Monteil, V.-M. 1996. Le livre de l'Inde. Selected excerpts, translated from Arabic, with annotations. UNESCO. Arles/Paris.

Radhakrishnan, S. 1953. The Principal Upanișads. London. Reprint: Atlantic Heights, NJ, 1992.

Renou, L. 1963. "Sur le genre du sūtra dans la littérature sanskrite”. Journal Asiatique 251: 165-216.

Sachau, E. C. 1910. Alberuni's India. 2 vols. London.

Sarasvati Amma, T. 1999. Geometry in Ancient and Medieval India. 2nd edn. rev. Delhi.

Sarma, K. V. 2008. Gaṇita-Yukti-Bhāṣā of Jyeșṭadeva. With Explanatory Notes by K. Ramasubramanian, M. D. Srinivas, and M. S. Sriram. Berlin.

Seidenberg, A. 1962. "The Ritual Origin of Geometry". Archive for History of Exact Sciences 1: 488-527.

Sen, S. N. and A. K. Bag. 1983. The Ślbasūtras of Baudhāyana, Āpastamba, Kätyāyana and Mānava, with Text, English Translation and Commentary. New Delhi.

Staal, F. 1999. "Greek and Vedic Geometry". Journal of Indian Philosophy 27: $105^{-127 .}$ 
Staal, F. 2001. "Squares and Oblongs in the Veda". Journal of Indian Philosophy 29: 257-273.

Thibaut, G. 1875a. "On the Sulva-sūtra”. Journal of the Asiatic Society of Bengal 44:227-275. 1875b. Baudhāyana Śulva-sūtra. Edited and translated with commentary by Dvārakānātha Yajvā. The Paṇdit, os 9-10 (1874-1875), ns 1 (1877). Benares. Thibaut's translations and comments were reprinted as Mathematics in the Making in Ancient India. Calcutta, 1984. 